\title{
COMMEMORATION, REMEMORATION AND REFORMATION: SOME HISTORICAL-HERMENEUTICAL REMARKS IN LIGHT OF THE 1917 REFORMATION CELEBRATIONS OF THE DUTCH REFORMED CHURCH ${ }^{1}$
}

\section{Robert Vosloo}

Stellenbosch University

rrvosloo@sun.ac.za

\section{ABSTRACT}

In 2017 the $500^{\text {th }}$ anniversary of the Reformation will be commemorated worldwide through various conferences, church and cultural events, and publications, also in Southern Africa. How should we commemorate the $16^{\text {th }}$-century Protestant Reformation in 2017 in Reformed circles in Southern Africa? Against the backdrop of this question, this article argues for the need of a self-critical reflection on the possible abuses associated with commemorations as such, as well as by a heightened historical consciousness of the way in which past commemorations of the Reformation functioned in processes of identity construction and 'othering'. With this in mind, the article proceeds in two parts. In the first part the aspect of

1 This article was read as a paper at the annual conference of the Church Historical Society of Southern Africa, held in Potchefstroom from 13-15 August 2015. The theme of the conference was 'Remembrance and Commemoration.'

\section{UNISA $\cong$}

Studia Historiae Ecclesiasticae Volume 41 | Number 3 | 2015 pp. 79-91
DOI: http://dx.doi.org/10.17159/2412-4265/2015/764 Print ISSN 1017-0499 | Online 2412-4265 (C) 2015. Studia Historiae Ecclesiasticae 
commemoration is problematised by referring to the critique of the possible abuses of memory associated with commemorations, as highlighted in the work of Tzvetan Todorov, also with reference to his distinction between commemoration and rememoration. The second part of the article then turns to some historical documents that give us a glimpse into the $400^{\text {th }}$ anniversary of the Reformation in 1917 in Reformed circles in South Africa, and specifically within the Dutch Reformed Church. This is followed by some concluding remarks.

Keywords: Commemoration; Memory; Todorov; Reformation; 1917 Reformation Celebrations; Dutch Reformed Church

\section{INTRODUCTION}

On 31 October 1517 the Augustinian monk Martin Luther allegedly posted his 95 theses on the door of the castle church in Wittenberg, and this event has been seen as a symbolic historical marker indicating the beginning of the $16^{\text {th }}$-century Protestant Reformation. In 2017 the $500^{\text {th }}$ anniversary of the Reformation will be commemorated worldwide through various conferences, church and cultural events, and publications. The Luther Decade was launched in 2008 already, focusing on a specific theme each year in light of the legacy of the Reformation and the role of Martin Luther in particular (www.luther2017.de/en/).

What is interesting about the commemoration process thus far, as well as about the planned events and projects, is the fact that it is consciously ecumenical and global. As we read on a Reformation Anniversary website:

While celebrations in early centuries were kept national and confessional, the upcoming anniversary...ought to be shaped by openness, freedom and ecumenism. In 2017 we aren't just celebrating 500 years of Reformation, but we are reminded of the role the Reformation played in the development of the modern age... What started in Wittenberg in the $16^{\text {th }}$ century changed Germany, Europe and the whole world. ( www.luther2017.de/en/2017/ reformationsjubilaeum/)

With regard to this ecumenical and global focus, a joint project of the Lutheran World Federation (LWF) and the Pontifical Council for Promoting Christian Unity (PCPCU) can be mentioned. In 2013 the Lutheran-Roman Catholic Commission on Unity published their report From conflict to communion: Lutheran-Catholic common commemoration of the Reformation in 2017. Already in the foreword of this report we sense the ecumenical commitment to the unity of the church as well as the sense of the pain and harm caused by historical divisions and polarisation, thus seeking a way from 'conflict to communion'. ${ }^{2}$ To commemorate the Reformation in

2 We read, for instance: 'In 2017 we must confess openly that we have been guilty before Christ of damaging the unity of the church. This commemorative year presents us with two challenges: the purification and healing of memories, and the restoration of Christian unity in accordance with the 
an ecumenical and global age, however, is no easy task and the report mentions three main challenges which provide opportunities and obligations for the commemorative process:

(1) It is the first commemoration to take place during the ecumenical age. Therefore, the common commemoration is an occasion to deepen communion between Catholics and Lutherans. (2) It is the first commemoration in the age of globalization. Therefore, the common commemoration must incorporate the experiences and perspectives of Christians from South and North, East and West. (3) It is the first commemoration that must deal with the necessity of a new evangelization marked by both the proliferation of new religious movements and, at the same time, the growth of secularization in many places. (The Lutheran World Federation and the Pontifical Council for Promoting Christian Unity 2013, 11)

These are indeed serious challenges to be dealt with in an attempt to commemorate the sixteenth-century Protestant Reformation in an ecumenical and global age. What is also of interest in the report is its sensitivity to the way in which political and church-political agendas had frequently shaped previous centennial commemorations. In 1617, for instance, the $100^{\text {th }}$ anniversary helped to stabilise and revitalise the common identity of Lutherans and Reformed Christians at their joint celebrations, held in a polemical relationship to the Roman Catholic Church. Luther became the liberator from the Roman yoke, while several centuries later, amidst the calamity of the First World War in 1917, Luther was portrayed as a German national hero (The Lutheran World Federation and the Pontifical Council for Promoting Christian Unity 2013, 12).

In this article I do not offer a detailed reading or critique of the report From conflict to communion. ${ }^{3}$ Rather, in the background is the question of how to commemorate the sixteenth-century Protestant Reformation in 2017 in Reformed circles in Southern Africa. I share, though, the emphasis in From conflict to communion on the need for a common commemoration over against isolationist celebrations that fuel polarisation, also in the light of past conflicts and the internal divisions within Reformed churches in Southern Africa, as well as between various denominations and churches. Against this backdrop, this article argues that the 2017 Reformation commemoration by Reformed churches in Southern Africa should be accompanied by a self-critical reflection on the possible abuses associated with commemorations as such, as well as by a historical consciousness of the way in which past commemorations of the Reformation functioned in processes of identity construction and 'othering' (in which 'the other' is often demonised, silenced or excluded). With this in mind, the article proceeds in two parts. In the first part the aspect of commemoration is problematised by referring to the critique of the possible abuse of memory associated with commemorations, as highlighted in the work of Tzvetan Todorov (1995; 2000; 2001;

truth of the gospel of Jesus Christ (Eph 4:4-6)' (From Conflict to Communion 2013, 7).

3

See in this regard the essay by Oberdorfer (2014). 
2010; 2014), including his distinction between commemoration and rememoration. The second part of the article then turns to some historical documents that give us a glimpse into the $400^{\text {th }}$ anniversary of the Reformation in 1917 in Reformed circles in South Africa, and specifically within the Dutch Reformed Church. Here I will draw especially on the Dutch Reformed Church's official publication De Kerkbode (which later on became Die Kerkbode) as well as a booklet commissioned by the Federal Council of the Dutch Reformed Churches, and written by G.B.A. Gerdener, entitled Het Vierde Eeuwfeest (The Fourth Centenary).

\section{COMMEMORATION AND THE ABUSE OF MEMORY (TZVETANTODOROV)}

One scholar who has written on the abuses of memory, and has specifically indicted the frenzy of contemporary commemorations, is the French writer of Bulgarian descent, Tzvetan Todorov. Todorov has written an influential essay Les Abus de la mémoire (1995), although here I will draw mainly on some perspectives on commemoration from his book Hope and memory: Reflections on the twentieth century (first published in French in 2000 under the title Mémoire du mal, tentation du bien: Enquêtesur le siècle, and first published in English in 2003). In the preface to Hope and memory Todorov writes: 'Memory - one of the main themes of this book - should not be used only to celebrate one's own heroes, to mourn one's own dead, and to stigmatise the wrongs committed by others' $\left(2014\right.$, xxi). ${ }^{4}$ Memory is indeed a theme Todorov explores in his brief political history of the $20^{\text {th }}$ century - a century that can be described as the age of totalitarian regimes. According to Todorov $(2014,113)$, the totalitarian regimes of the $20^{\text {th }}$ century sought to achieve total control of memory. ${ }^{5}$ What is of interest in Todorov's discussion of memory, furthermore, is his warning against the unconditional support of memory, because as he puts it, 'the stakes of memory are too high for us to allow them to be dictated by enthusiasm or anger' $(2014,119)$. For Todorov memory, undefined, is neither good nor bad in itself and its benefits can be neutralised in several ways, for instance, through the sacralisation or the trivialisation of the past. Todorov observes: 'We can fall into the frying pan of making the past sacred and thus isolating it completely from the present; and we can fall into the fire by making it trivial, by seeing the present exclusively through

4 Or as Todorov writes in Memory as a remedy for evil: 'The memory of the past will serve no purpose if it is used to build an impassable wall between evil and us, identifying exclusively with irreproachable victims and driving the agents of evil outside the confines of humankind' (2010, 79-80). And he ends this small book with the words: 'The memory of the past could help us in this enterprise of taming evil, on the condition that we keep in mind that good and evil flow from the same sources and that in the world's best narratives they are not neatly divided' $(2010,88)$.

5 For a discussion of the anti-totalitarian humanism of Todorov (and Levinas), see Terreblanche (2007). 
the lens of the past' $(2014,161)$. Put differently: 'A sanctified past brings nothing to mind but itself; a trivialised past reminds of anything and everything' $(2014,164)$.

Todorov is clearly concerned with the abuses of memory, and opens space for the question of whether memory is necessarily a good thing ${ }^{6}$ and forgetting always a curse. Of special concern for our purposes here is the distinction that Todorov makes between testimony, history and commemoration. The traces of the past that live on in the present fall, according to Todorov, into a variety of discourses, and he highlights especially the language of testimony, the language of history and the language of commemoration. Testimony is the type of discourse that arises when we summon and recount memories as we give meaning to our lives and construct our identity. Although this form of memory-work may use documents or other material traces, it is by definition solitary work, and nobody can tell us what image to have of our own past. The historian, on the other hand, is attached to the discipline that seeks to recover and analyse the past, with the concomitant commitment to seek the truth. Todorov writes:

Historians often have reservations about testimonial literature. Not only do they attract lots of readers, but until they have been examined with the tools of historical scholarship (which often proves to be impossible), they have little truth value. Witnesses for their part, mistrust historians - because they weren't there, they didn't suffer physically, they were still in short pants or not even born when the event took place. This undeclared war can be settled, all the same, if we could grant that testimony, even if it does not respect the criterion of truth in the way that history must, nonetheless enriches historical discourse. $(2014,130)$

But, Todorov continues, the past does not only live in the present through testimonial literature or historical inquiry, but also through commemoration. He observes: 'Like the witness the commemorator is pursuing his or her personal interest; but in common with professional historians, celebrants operate in the public sphere and aspire to irrefutable truthfulness, as far as possible from the unreliability of personal accounts' $(2014,132)$. Whereas Todorov sees some possible complementarity between historians and witnesses, he is less optimistic about the compatibility of celebrants and historians, given the fundamental difference of aims and methods. Although the discourse of commemoration suggests objectivity and truthfulness, it is - according to Todorov - not objective at all. Todorov comments: 'While history makes the past more complicated, commemoration makes it simpler, since it most often supplies us with heroes to worship or with enemies to detest, it deals in desecration and consecration' $(2014,133)$. He then makes a helpful

6 Todorov writes in this regard: 'Memory should not be thought of as a mechanical recording of what happened. It has many forms and functions, and we have to choose between them; it develops in stages, each of which can be distorted or disturbed; it can be possessed by different people who derive different moral attitudes from it. Is memory necessarily a good thing? Is forgetting always a curse? Does the past always help us to understand the present, or can it serve to confuse our view of the here and the now? Are all uses of the past permissible?' (Todorov 2014, 3). 
distinction between rememoration and commemoration: 'Rememoration is to try and grasp the truth of the past. Commemoration is to adapt the past to the needs of the present' (Todorov 2014, 133).

In this regard Todorov defends the notion of revisionism, understood in a certain way. He does not mean the form of revisionism that is associated with negationism (for instance, that the gas chambers in German concentration camps did not exist), but rather in a way that sees historical truth as always subject to revision. For him this kind of revisionism stands over against pious or sanctified history, which is what the discourse of commemoration is made of. Todorov admits that commemoration may be inevitable, but for him it is not the best way to make the past live on in the present. In a democracy we need something other than sanitised and sanctified images of the past. As he puts it: 'In our world human values, not monuments should be holy' $(2014,134)$. Or put differently, the use of memory should be linked to continuing responsible action in its name in the present: 'It can be very gratifying to commemorate the victims of past crimes, but getting involved with the victims of today is much trickier' (Todorov 2014, 175). These statements reflect something of Todorov's overall concern to link memory to 'the good'. In his discussion on the uses and abuses of memory in his book Memory, history, forgetting ${ }^{7}$, Paul Ricoeur refers to Todorov's statement in Les Abus de la mémoire that the work of the historian 'is necessarily guided by the search, not for truth, but for justice' (Ricoeur 2004, 86). While Ricoeur has reservations about viewing truth and goodness as stark alternatives, he affirms the importance of the reorientation of the discussion of the abuses of memory under the auspices of the search for justice $(2004,86)$. One is also reminded in this regard of the concluding words of Todorov's essay 'The uses and abuses of memory': 'Far from remaining prisoners of the past, we must put it to the service of the present, just as memory - and forgetting - should be used in the service of justice' (Todorov in Marchitello 2001, 21-22).

I mention Todorov's emphasis on the link between memory and justice and some of his critical comments concerning commemoration here, because they foster a selfcritical attitude regarding possible abuses associated with remembering the past. If one reflects on commemoration, and specifically on the question how to commemorate the Reformation in Southern Africa in 2017, one would be well advised to take heed of Todorov's distinction between rememoration and commemoration, and guard against simplifying the past, which entails not taking the messiness and complexities of history seriously. In the process we should challenge commemorative strategies that glorify or reify 'our own' and demonise 'the strange' or 'the other', often leading to us becoming oblivious to the urgent challenges posed by current injustices that require responsible action. In Todorov's words:

7 For a more detailed engagement with Ricoeur's discussion of the abuses of memory, see Vosloo (2012). 
Ritual commemoration, when it only confirms a negative image of the other in the past or a positive image of the self, is ineffective as a tool for public education, and, what is worse, it is an easy way of giving us all a good conscience while averting our eyes from present emergencies...It is hard to find the path that skirts the pitfalls of sanctification and of trivialization, that leads us neither to serve only our own interests nor to give lessons only to others. But that strait and narrow path does exist. $(2014,175-176)^{8}$

\section{REVISITING THE 1917 COMMEMORATION OF THE REFORMATION IN THE DUTCH REFORMED $\mathrm{CHURCH}$}

In the previous section I called attention to some of the critical remarks raised by Todorov that challenge an uncritical enthusiasm for commemoration. The attempt to grapple with the question of how to commemorate or celebrate the Reformation in Reformed circles in Southern Africa in 2017 should, or so this article argues, take this critique of commemoration seriously. One can argue further that this question is not situated in a historical vacuum and that any reflection on responsible processes of commemoration of the Reformation in Reformed circles should take cognisance of the complex and ambivalent history of the Reformed churches in Southern Africa, including the history of commemorated practices associated with the Reformation. ${ }^{9}$ In this light, the article pays closer attention to some texts from Dutch Reformed Church circles that relate to the $400^{\text {th }}$ commemoration of the Reformation in 1917.

At the meeting of the Federal Council of Dutch Reformed Churches (the combined council of the various Dutch Reformed Synods) held in March 1917 in Graaff-Reinett, the commission tasked with the $400^{\text {th }}$ anniversary of the Reformation (consisting of W.A. Joubert, D.J. Pienaar, M.W. Odendaal and P.S. Van Heerden) reported that this festival should be celebrated in a special way and that this occasion should be used to make congregations attentive to the meaning of Protestantism and the principles that lie at the heart of the Reformation. This is viewed as important for the following reasons:

a. A lack of principled conviction ['beginselvastheid'] on the side of the nation [or people, volk], which the Roman Catholic Church ['de Roomsche kerk'] knows how to utilise in its favour.

8 Although Todorov acknowledges the right to affirm one's own identity, he speaks of the greater dignity associated with the concern for the misfortune of others, and writes in this regard: 'A French Jewish writer, André Schwarz-Bart, wrote a remarkable novel about the genocide of the Jews, The last of the just, and then devoted himself to the world of black slaves. When he was asked to account for this change, he replied: "A great rabbi once asked: Why is the stork, whose name in Jewish [sic] is hassida, meaning loving, because it loves its own, why is it classified as an unclean bird? The rabbi replied: 'Because it gives its love only to its own"' (Todorov 2014, 174). See in this regard, for instance, Plaatjies van Huffel and Vosloo (2013). 
b. The powerful action of Roman Catholicism with regard to the founding of schools and proselytising ['proselieten-makerij'].

c. The great ignorance among church members regarding the origin and history of the Protestant church.

d. A false conception of what freedom of religion entails, and the idea that Rome [i.e. the Roman Catholic Church] is not the same as in previous centuries and not concerned with the faith of Protestant believers (Acts of the Federal Council of DR Churches 1917, 78) [my translation and parenthesis].

In reading this report one is struck by the way in which the celebrations are motivated in light of the perceived threat posed by the Roman Catholic Church. The report also makes some suggestions on how the Reformation Festival is to be celebrated and suggests, among other things, that the government should be asked to declare 31 October 1517 a national public holiday; ${ }^{10}$ that worship services and conferences with a focus on the Reformation should be held on the Sunday closest to 31 October; that a short booklet should be written on the Reformation and distributed to congregations; and that special collections should be taken at the commemorative events for needy congregations ['hulpbehoevende gemeenten'] (Acts of the Federal Council of DR Churches 1917, 78-79) [my translation and parenthesis].

The commissioned booklet referred to in the recommendation was written by G.B.A. Gerdener, who later became professor at the theological seminary at Stellenbosch and a well-known figure in church, mission and ecumenical circles. Towards the end of Gerdener's 125-page historical overview of the Reformation, entitled Het Vierde Eeuwfeest. Gedenkschrift bij gelegenheid de Vierhonderste viering van de Kerkhervorming 1517-1917, he asks the following questions: 'Is the church situation in 1917 still the same as in 1517? Is there still a danger from the side of the Roman Catholic Church? Is there still persecution and heresies against which Protestants should protest?' (Gerdener 1917, 118). Gerdener feels, and thanks God for it, that the situation is indeed not the same in 1917 as in 1517. But, he continues, we should still be on our guard against the sly activities ('listige bedrijvigheid') of the Roman Catholic Church. He points to the fact that there have been no doctrinal changes in the Roman Catholic Church regarding the doctrines that Luther and Calvin protested against, and he lists some examples in this regard. He also calls his readers to guard against the Roman Catholic Church and its schools, pointing to the fact that the influence of the Roman Catholic Church has grown in recent years, a fact that he finds surprising:

10 This was indeed requested and the various provinces all responded positively, albeit in different ways. The replies from the various directors general of the provinces were published in $D e$ Kerkbode. 
One can hardly believe that a church that allows for so little freedom and that has a tradition of cruelty and persecutions behind it, can have an influence on our freedom-loving volk, a volk that has a great part of the blood of the Huguenots and the Sea Beggars in their veins ['dat voor ' $n$ groot deel het bloed van Hugenoten en Geuzen in de aderen heft']. $(1917,122)$

And, Gerdener continues, it is not intolerance that motivates us to warn against the Roman schools and the Roman Church. Rome should not be fought with the weapons of violence, but with the weapons of pure truth of the gospel. Some of the same sentiments expressed in the report of the commission tabled at the Federal Council of DR Churches are thus also found in the commissioned booklet.

The decision of the Federal Council was also published in full on 2 August 1917 in De Kerkbode, the official weekly DRC newspaper (1917, 741-742). In the same edition we find a letter from A.J. Louw (a moderator of one of the Synods) that encouraged joint celebrations between various Reformed congregations, and even with the two 'Hollandse kerke' (i.e. the other main white Afrikaans-speaking Reformed churches) (Louw 1917, 743-744). A month earlier the De Kerkbode had already reminded its readers about the upcoming commemoration of the Reformation and stated that it would publish various short articles ('vliegende blaadjes') in the months leading up to the celebrations around 31 October (De Kerkbode 5 July 1917, 651).

In most of these writings the same polemical tone against the Roman Catholic Church that marked the Federal Council's report is present. ${ }^{11}$ An article by Rev. A. McGregor in De Kerkbode of 5 July, however, is an interesting exception. He asks: 'In what spirit are we going to celebrate?' And then comments:

Certainly not in a merely polemical, anti-Roman Catholic spirit ['Seker tog in geen bloot polemischen, anti-roomsche geest']. Although we emphasise points of difference between us and the Roman Catholic church...we rejoice that in terms of the fundamental truths on the glory of God, human sin, the divinity of Christ, the atonement through the cross, the indwelling of the Spirit, life after death - we are one. We should not forget that our biggest enemy is not Roman Catholicism, but materialism and unbelief...If we celebrate this Festival only in a polemical manner it will be a failure. (McGregor 1917, 655)

In the following months several letters to the editor were published in De Kerkbode that protested against this statement. In De Kerkbode of 9 August W.P.J. Poen writes that he read the comments by McGregor with astonishment, and that he could not believe his eyes when he read these words from one of the most learned ministers in the church.

We one with Rome with regard to the glory of God! How can the glory of God find the right expression when the Protestant doctrine of election is not only negated, but scolded as a hellish, God-dishonouring monstrosity? ['maar als een helsch, God-onteerende monstrositeit

11 See, for instance, the articles in De Kerkbode of 2 August, 9 August, and 20 September 1917a,b,c by Rev. H.E. du Plessis. 
uitgekreten wordt?'] (Poen 1917, 783), [my translation and parenthesis, emphasis in the original].

And he goes on to speak in a similar vein of all the other doctrinal matters that McGregor mentioned. ${ }^{12}$

De Kerkbode was also used as a mouthpiece to call upon congregations to make the most of the celebrations, and it sought to contribute theologically to these commemorations. On 18 October a special edition ('praguitgawe') of 60 pages was distributed as an addendum to the regular edition of De Kerkbode. This richly illustrated edition contains articles on 'The Reformations and its Leaders' (extensive articles on both Luther and Calvin); 'The Reformation in Geneva under Calvin'; 'The Reformation in the Netherlands'; two articles on 'The Reformation and the Huguenots'; an article aimed at the youth ('Oom Willem Smit on the Reformation'), 'Reformation Hymns'; 'The Reformation's doctrine of the Church'; 'The Reformation and the family'; and 'The Reformation and mission.' This commemorative edition also included a sermon by Rev. P.S. van Heerden on 'The Reformation - A new day: The night has passed'. In the sermon he speaks of the darkness of the Middle Ages (with its night of ignorance, night of injustice and night of superstition), followed by the coming of day that dawned with the new emphasis on the Bible, and on justification by faith. As children of the light, moreover, we have responsibilities. The sermon also portrays a sense of being beleaguered. 'Enemies surround us. Life is a struggle. Therefore we must take up the weapons of the light, and stand in the full armour of God' (Van Heerden 1917, 59).

The opening contribution in the commemorative booklet by Rev, D.J. Pienaar is, however, quite self-critical. It starts with the words: 'Het is thans feesttijd, vreugdetijd, jubeltijd voor het Protestantisme' [It is now a time of festivity, a time of joy, a time of jubilation for Protestantism'] (Pienaar 1917, 1). Yet, Pienaar continues, there are also circumstances that can invite the question whether our exuberant tone should not change to one of lament, and whether the time of feasting should not change into a time of fasting $(1917,1)$. The land of Luther and Calvin, the countries of the Reformation, are in mourning amidst the horrific and bloody realities of war. Pienaar is also sensitive to the fact that the Reformation created a break in the one body of Christ and therefore the celebrations cannot be a matter of unqualified joy. Yet Pienaar nevertheless believes that the Reformation can be commemorated with gratitude and joy. The self-critical sentiments by Pienaar, however, are the exception rather than the rule in the writings found in De Kerkbode in the months preceding the Reformation celebrations, and the dominant impression is rather of a polemicising discourse that sought to strengthen an isolationist and beleaguered identity.

12 The same objections are also found in a letter by P.J. Marais, published in De Kerkbode of 13 September 1917. 
It seems indeed the case that the Reformation was commemorated in a festive way around the time of 31 October 1917. De Kerkbode later reported on large events being held in Cape Town at the Groote Kerk, and in Johannesburg at the Civic Hall (with 3000 people attending). From the extensive feedback in De Kerkbode on these events it seems that the same anti-Roman Catholic rhetoric persisted at these events as well (De Kerkbode 8 November 1917, 1094-1095).

\section{CONCLUSION}

This brief survey of the glimpses one gets through De Kerkbode and other commemorative publications on the 1917 celebrations of the Reformation in the Dutch Reformed Church, reveals a polemical stance against the Roman Catholic Church, with the focus more on 'conflict' than on 'communion' (to use words from the report From conflict to communion mentioned in the introduction). Although not uncontested, this antithetical approach seems to be the dominant paradigm in the commemorative discourse. Maybe this is indicative of the Dutch Reformed Church's struggle with the modernism and the liberalism that characterised theological debates in the first decades of the $20^{\text {th }}$ century, culminating in the Du Plessis case and a certain form of neo-Calvinism that became entrenched in its wake.

What will the dominant mode characterising the 2017 celebrations within Reformed circles be in Southern Africa? Time will tell, but in the light of the above comments, I suggest that the following aspects should be kept in mind.

- The need for a self-critical engagement with the possible abuses associated with commemorations. This means, among other things, that commemoration should not be abstracted from rememoration. Amidst their differences, the link between personal testimony (memory), history and commemoration should be maintained. The pragmatic concerns associated with commemoration should not override an honest and hermeneutically responsible engagement with the past through historical inquiry, including sensitivity to the complex and ambivalent historical contexts in which past commemorations took place.

- One should guard against strategies of identity construction and 'othering' that blind one to urgent current challenges and opportunities. Hence the importance of asking the question: With what future in mind we are commemorating the Reformation? In terms of Todorov's work, this means that we ask about the ethics of commemoration. Are our commemorations linked to concerns for justice?

- The emphasis on common commemoration in an ecumenical and global age holds much promise for a deeper understanding of our Christian tradition and may lead to a new appreciation of the contributions that insights from the 
Protestant tradition can bring to the table in contemporary discourses on what lies at the heart of the nature and mission of the church in our world today.

- Celebrations that are not touched by a spirit of confession about the disunity of the church will be unauthentic and in the end produce simplistic categorisations.

With regard to this last point, a sermon by Dietrich Bonhoeffer comes to mind. In 1932, amidst trying times, he preached on Reformation Sunday in Berlin, using as his text Revelation 2:4-5, 7: 'But I have this against you, that you have abandoned the love you had at first. Remember then from what you have fallen; repent, and do the works that you did first. If not, I will come to you and remove your lampstand from its place, unless you repent...Let anyone who has an ear listen to what the Spirit is saying to the churches. To everyone who conquers, I will give permission to eat from the tree of life that is in the paradise of God.' Let me end with a quote from this remarkable sermon.

The Protestant church is observing a special day. Protest is among its traditional obligations. It must protest against quite a variety of things, but protest it must. This time it is a strong protest against secularization in the form of godlessness, but of course also - perhaps especially this time - against Catholicism and its dangers (meaning, of course, only the political dangers)... Oh, how easily we protest, with passion and self-confidence, since we have a documented right to it. But God says: "I have this against you... meaning, 'I protest."” God protests - against whom? Against us and our protest! Can't we hear it? Protestantism is not about us and our protest against the world, but rather about God's protest against us. (Bonhoeffer 2009, 441)

\section{REFERENCES}

Bonhoeffer, D. 2009. Berlin: 1932-1933: Dietrich Bonhoeffer Works, Vol.12. Minneapolis: Fortress Press.

Du Plessis, H.E. 1917a. 'Het Onderscheid tusschen het Protestantisme en het Roomsche Catholiscisme.' De Kerkbode, 2 August 1917: 747-748.

Du Plessis, H.E. 1917b. 'De Hugenoot en de Hervorming.' De Kerkbode, 9 August 1917: 769-770.

Du Plessis, H.E. 1917c. 'Het verskil tussen onse leer en die Roomse.' De Kerkbode, 20 September 1917: 930.

Gerdener, G.B.A. 1917. Het Vierde Eeuwfeest. Gedenkschrift bij gelegenheid van de Vierhonderdste Viering van de Kerkhervorming. Cape Town: De Zuid-Afrikaanse Bijbel Vereniging.

Louw, A.J. 1917. 'Het Vierde Eeuwfeest der Kerkhervorming, 1 Oct. 1917: De viering in de Transvaal.' De Kerkbode, 2 August 1917: 743-744.

Marais, P.K. 1917. 'Het Vierde Eeuwfeest der Kerkhervorming.' De Kerkbode, 13 September 1917: 901.

McGregor, A. 1917. 'Het Vierde Eeuwfeest der Hervorming.' De Kerkbode, 5 July 1917:654-655. 
Oberdorfer, B. 2014. Feiern? Gedenken? Büssen? Ökumenische Perspektiven auf das Reformationsjubilaum: Zur lutherisch-katholischen Studie 'Vom Konflik zur Gemeinschaft.' Materialdienst des Konfessionskundlichen Instituts Bensheim 64. Heft 1,3-8.

Pienaar, D.J. 1917. 'De Hervorming - Gods werk.' In Het Vierde Eeuwfeest der Kerkhervorming. Supplement De Kerkbode, 18 October 1917, 1-6.

Plaatjies van Huffel, M. and Vosloo, R.R. 2013. Reformed Churches in South Africa and the struggle for justice: Remembering 1960-1990. Stellenbosch: Sun Media.

Poen, W.P.J. 1917. 'Het Vierde Eeuwfeest der Kerkhervorming.' De Kerkbode, 9 August 1917: 783-784.

Terreblanche, S.J. 2007. 'Todorov, Levinas and anti-totalitarian humanism: A perspective on contemporary utopian thought.' HTS 63(1): 301-325.

The Lutheran World Federation and the Pontifical Council for Promoting Christian Unity. 2013. From Conflict to Communion: Lutheran-Catholic Common Commemoration of the Reformation in 2017. Leipzig: Evangelische Verlagsanstalt.

Todorov, T. 1995. Les Abus de la mémoire. Paris: Éditions Arléa.

Todorov, T. 2000. Mémoire du mal, tentation du bien: Enquêtesur le siècle. Paris: Éditions Robert Laffont.

Todorov, T. 2001. 'The uses and abuses of memory.' In What happens to history: The renewal of ethics in contemporary thought, edited by Marchitello, H. New York: Routledge.

Todorov, T. 2010. Memory as a remedy for evil. London: Seagull Books.

Todorov, T. 2014 [2003]. Hope and memory: Reflections on the twentieth century. London: Atlantic Books.

Ricoeur, P. 2004. Memory, history, forgetting. Chicago: University of Chicago Press.

Van Heerden, P.S. 1917. 'De Hervorming - Een Nieuwe Dag. De Nacht Voorbijgegaan.' In Het Vierde Eeuwfeest der Kerkhervorming. Supplement De Kerkbode, 18 October 1917: 55-59.

Vosloo, R.R. 2012. 'Memory, history, and justice: In search of conceptual clarity.' Dutch Reformed Theological Journal (NGTT) 53: 215-227.

http://www.luther2017.de/en/ (accessed 10 August 2015).

http://www.luther2017.de/en/2017/reformationsjubilaeum/ (accessed 10 August 2015). 